\title{
The Effect of Student Activity in Organizations on Learning Achievement and Soft Skill Improvement
}

\author{
Pipit Ramadhanti ${ }^{1}$, Tjetjep Yusuf Afandi ${ }^{2}$, Efa Wahyu Prastyaningtyas ${ }^{3}$ \\ ${ }^{1,2,3}$ Department of Economics Education, Nusantara PGRI University, Kediri, Indonesia \\ Corresponding Author: Pipit Ramadhanti
}

\begin{abstract}
The purpose of the study was to determine whether student activity in the organization affected learning achievement and soft skills improvement. This study used a descriptive quantitative approach; data collection techniques used was the questionnaire method. The research population was 365 students of the Faculty of Economics and Business, UNP Kediri class of 2018. The samples were taken using a purposive sampling technique with a total of 79 students. Data analyses used were validity, reliability, normality, multicollinearity, heteroscedasticity tests, simple regression analysis techniques, hypothesis testing and determination tests (R2). This study used SPSS software version 23 which showed the results of the t-test of learning achievement variable values with a sig of $0.46<0.05$, while the t-test value of the soft skills variable with a sig of $0.00<0.05$, the value of sig $f_{\text {count }}>f_{\text {table }}$ with a total of $3,970 \mathrm{f}_{\text {tables}}$, simultaneously student activity in the organization had a positive and significant influence on learning achievement and improvement of soft skills on Economics and Business students of Nusantara PGRI University, Kediri.
\end{abstract}

Keywords: Organization, Learning Achievement, and Soft Skills

\section{INTRODUCTION}

Higher education is an educational institution that also functions as a medium of education and a place to channel values and knowledge between educators called lecturers and students. From the educational process, it is hoped there will form a generation that is qualified, superior and able to provide a relevant role to the surrounding community and for the progress of the nation and country. With the existence of quality education will form a superior person, can create a competitive advantage in global competition. One of the places to form a quality energy source is through educational institutions such as colleges or universities.

Higher education is a formal educational institution whose duty and responsibility is to prepare students and create graduates who are of good quality, excelling in hard skills and soft skills, as well as to bridge students in actualizing talents and interests through UKM (Student Activity Unit). Based on previous research by, (1) there is significant effect to the students who participate in Students Activity Unit in shaping their soft skill. It shows that the activeness of students in the organization is one of the external factors that affect learning achievement. This is also reinforced by (2) which state that organizational activity has a positive and significant effect on learning achievement.

Soft skills are skills and life skills for oneself, in groups, or in society, and with God (3). In line with research (4) that student activity in organizations affects soft skills because it can grow soft skills for students so that students' soft skills are increasing and able to be used as provisions before heading to the world of work. Students of the Faculty of Economics and Business, Nusantara PGRI University, Kediri Class of 2018 became the object of 
research with a total of 365 students. To produce quality, competent, superior human resources, the Nusantara University PGRI, Kediri campus has prepared adequate facilities through the organization.

There are two student organizations at the Nusantara PGRI University, Kediri, they are Lemawa (Student Institution) and Ormawa (Student Organization). Lemawa which consists of the University-Student Executive Board (USEB), Student Representative Council (SRC), Student Election Commission (SEC), Student Election Supervisory Board (SESB), Student-Faculty Executive Board (SFEB), Student Association (SA). Meanwhile, Ormawa includes Student Activity Units (SAU), including: UKM UKKI (Islamic Spiritual Activity Unit), KSR (Voluntary Corps), SAU: FIB CARAKA (Caraka Business Incubator Forum), SAU: MENWA (Student Resisment), SAU: MAPALA (Nature Adventurer Students) ), SAU: Adab Theater, SAU: PADUS (Choir), SAU: SCOUT, SAU: KK (Christian Spirituality), SAU: Basketball, SAU: PPN (Research and Reasoning), SAU: Dance and musical, SAU: PIK-R (Information and Counseling Center for Youth of Perisai Nusantara), SAU: PSHT.

Some of the phenomena that occur can be described as follows: 1) Some students spend time in organizing only to be used as spare time fillers or waiting for the next course so that organizational activities have not been carried out optimally; 2) Students prefer to play rather than spend their time following the organization to seek experience; 3) Student learning achievement declines because students who are active in organizations ignore the tasks given by the lecturer; and 4) the contribution of the organization in improving the soft skills of students to advance in facing the industrial world has not yet been seen and many students still underestimate or underestimate and do not know about the importance of having soft skills on the other hand to face the world of work or the community environment because, beside hard Soft, soft skills are also needed in life and do not rule out economic activities.

Universities facilitate students to accommodate and practice their talents and interests through UKM (Student Activity Units), in addition to producing hard skills by joining organizations, what is meant by being active in the organization here is to meet the following criteria: have commitment, empathy, responsiveness, participation, accountability, and adaptability, by joining the organization will improve soft skills which will later be needed in the world of work or society in order to create a competitive advantage and be able to compete globally.

\section{LITERATURE REVIEW}

Table 1: Organization Description

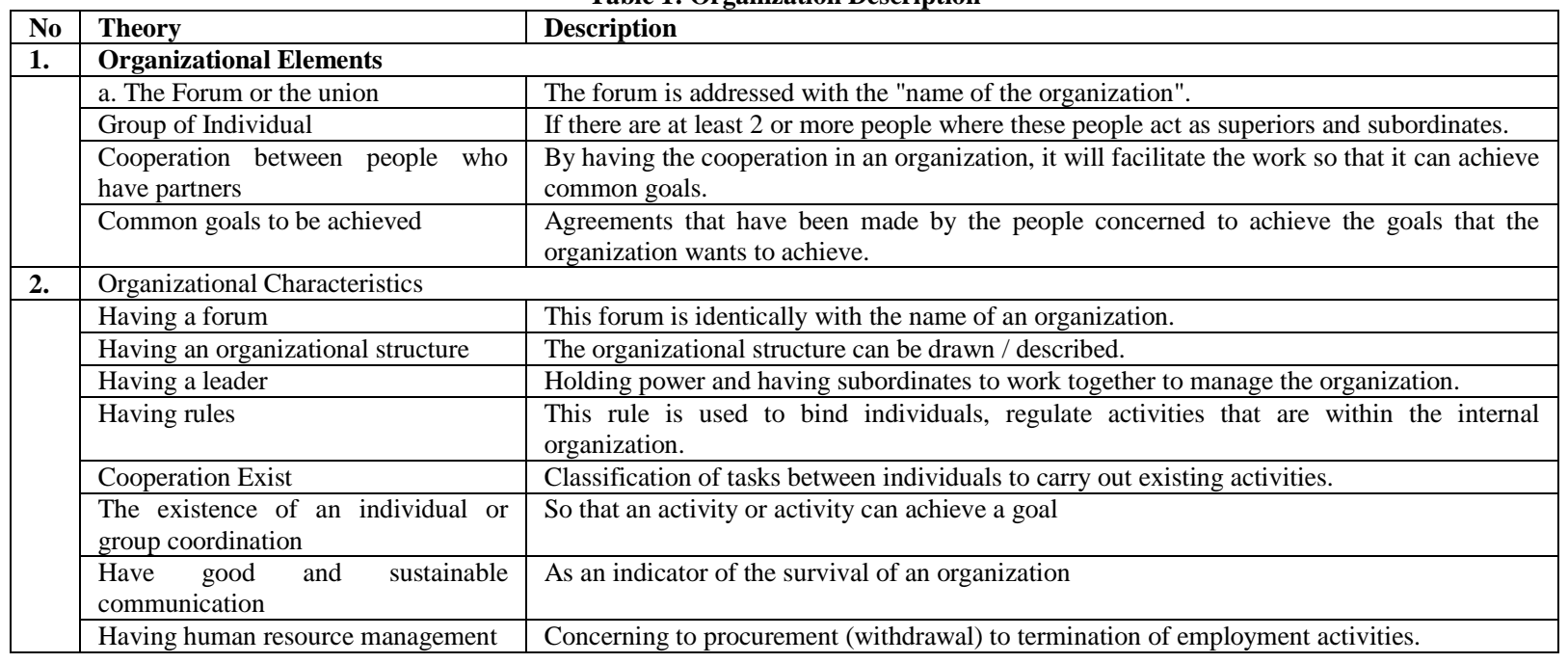


Pipit Ramadhanti et.al. The effect of student activity in organizations on learning achievement and soft skill improvement.

\begin{tabular}{|c|c|c|}
\hline \multicolumn{3}{|r|}{ Table 1 Continued... } \\
\hline \multirow[t]{3}{*}{3.} & \multicolumn{2}{|l|}{ Organizational benefits and functions } \\
\hline & \multicolumn{2}{|l|}{ Organizational benefits } \\
\hline & Helping in providing direction & In making an effective plan and its implementation. \\
\hline & $\begin{array}{l}\text { Able to provide motivation and } \\
\text { enthusiasm }\end{array}$ & To individuals in carrying out activities or activities in the organization. \\
\hline & $\begin{array}{l}\text { Help introduce the existence of the } \\
\text { organization }\end{array}$ & To the community and institutions. \\
\hline & $\begin{array}{l}\begin{array}{l}\text { Helping the leadership } \\
\text { organization }\end{array} \\
\end{array}$ & . In coordinating the subordinates and in making policies of an organization. \\
\hline & Organizational Function & \\
\hline & As a guidance in planning the work pro & ram of an organization. \\
\hline & As a basis or reference in implementing & he organization's program of activities. \\
\hline & As a standard in the success or failure $\mathrm{o}$ & an organization. \\
\hline
\end{tabular}

Organization is a forum or any form of human cooperation union (which inside is an organizational structure, division of tasks, rights and responsibilities) to achieve a common goal which consists of a group of people who work together. The organization is a place that allows people to achieve results that previously could not be achieved by individuals alone (5).

Achievement can be defined as the results obtained because of the learning activities that have been done. Achievement is something that has been shaped and produces an activity, an encouraging effort that is obtained with tenacity of work (6). Learning achievement has three aspects, among others: cognitive aspects, effective aspects, and psychomotor aspects (7).

Table 2 Differences in Internal Factors and External Factors Affecting Learning Achievement

\begin{tabular}{|c|c|c|}
\hline No & Internal Factors & External Factors \\
\hline \multirow[t]{4}{*}{1.} & Physiological Factors & Family Environmental Factors \\
\hline & a. Body Health & a. Family social economy \\
\hline & b. The five senses & b. Parents education level \\
\hline & & Parents' attention \\
\hline \multirow[t]{5}{*}{2.} & Psychological Factor & School Environmental Factors \\
\hline & a. Intelligence & Facilities and infrastructure \\
\hline & b. $\quad$ Behavior & $\begin{array}{l}\text { b. Competence of teachers and } \\
\text { students }\end{array}$ \\
\hline & $\begin{array}{ll}\text { c. } & \text { Talent }\end{array}$ & $\begin{array}{ll}\text { c. } & \begin{array}{l}\text { Curriculum and teaching } \\
\text { methods }\end{array}\end{array}$ \\
\hline & Attention & \\
\hline \multirow[t]{3}{*}{3.} & - & $\begin{array}{l}\text { Community Environmental } \\
\text { Factors }\end{array}$ \\
\hline & - & a. Socio-cultural \\
\hline & - & b. Participation in education \\
\hline
\end{tabular}

Soft skills are skills possessed by someone that will be useful for themselves, in groups, or in society. By having soft skills, one's existence will be more visible and felt in a society. Skills in communication, emotional, linguistic, group skills, have ethics and character, polite and spiritual skills (3). Soft skills are divided into two types, namely: 1) Personal Skills, which consist of a sense of responsibility, self-confidence, able to socialize, able to control oneself (self management) and integrity or honesty. 2) Interpersonal Skills, which consist of leadership, the ability to negotiate, able to collaborate in teams, willing to share knowledge with others, and being able to entertain clients or customers (8). Soft skills development requires three important events including: 1) Hard work 2) Independence 3) Teamwork (8). (9)

The influence of student activity in organizations on learning achievement and improvement of soft skills in faculty of Economics and Business students of Nusantara University PGRI Kediri class 2018 can be described with the following framework:

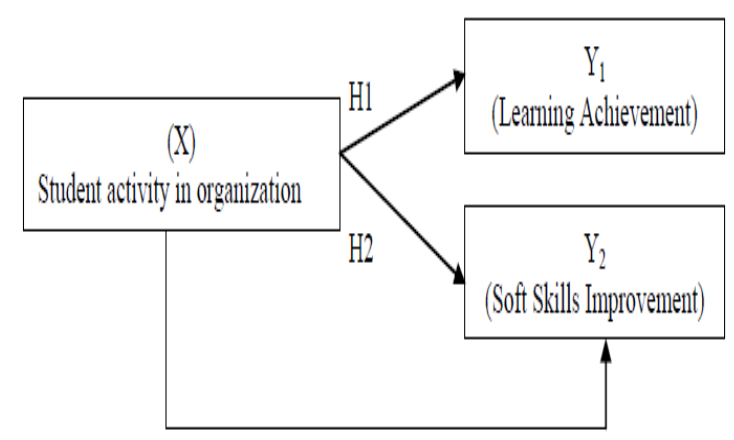

Figure 1: Conceptual Framework

Notes:

$\mathrm{X} \quad$ : Student activity in organizations

$\mathrm{Y}_{1} \quad$ : Learning achievement

$\mathrm{Y}_{2} \quad$ : Soft Skills Improvement

H1 : Hypothesis 1

$\mathrm{H} 2$ : Hypothesis 2

H3 : Hypothesis 3 
$\longrightarrow$ : The effect of student activity in the organization on learning achievement

$\longrightarrow$ : The effect of student activity in the organization on the improvement of soft skills

$\longrightarrow$ : The effect of student activity in the organization on learning achievement and improvement soft skills

\section{MATERIALS \& METHODS}

This study used a quantitative approach because the data analysis required was based on the data obtained from the respondents, which was then analyzed based on statistical methods (9). The data collection technique used a questionnaire. The population of this study was all students of the Faculty of Economics and Business, Nusantara PGRI University of Kediri class of 2018, totalling 365 students based on data obtained by researchers. The details of this population included 18 students in economic education, 260 in management, and 79 in accounting. The number of samples taken by the researchers amounted to 79 respondents. Sampling used was purposive sampling technique with the number of samples taken was 79 students. This study used SPSS version 23. The data analysis used were validity test, reliability test, normality test, multicollinearity test, heteroscedasticity test, simple regression analysis technique, hypothesis test and determination test.

\section{Statistical Analysis}

In this study, the classical assumption tests were normality test, multicollinearity test, autocorrelation test, and heteroscedasticity test. The explanation of the classical assumption test was as follows:

\section{a. Normality test}

Based on Figures 2 and 3 above which were the results of the normality test, it was known that the points spread and deviate away from the diagonal line and follow the line towards the normal distribution pattern. This shows that the normality test was normally distributed and feasible to use.

\section{Normal P-P Plot Regression \\ Standardized Residual \\ Dependent Variable: Learning \\ Achievement}

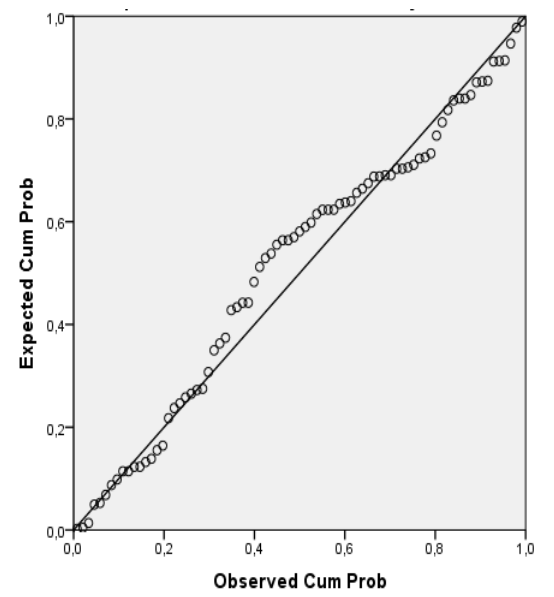

Figure 2: Learning Achievement Normality Test Results

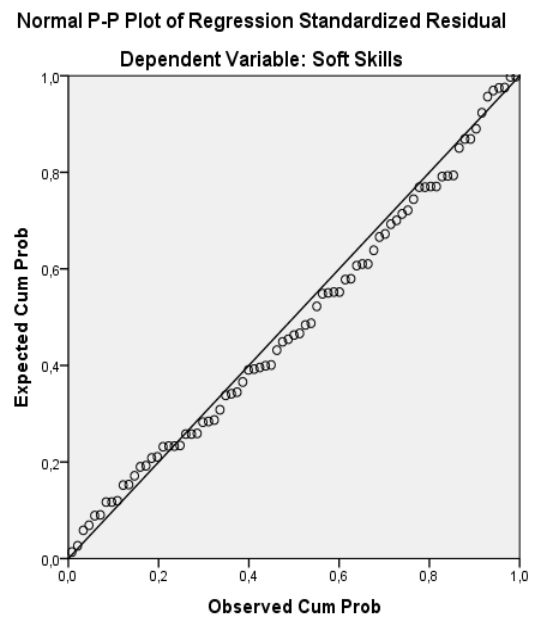

Figure 3: Soft Skills Normality Test Results

\section{b. Multicollinearity Test}

Based on table 3 and table 4 , it showed that the independent variable had a tolerance greater than 0.01 and a VIF value less than 10, the tolerance value was 01,000 and the VIF value was 01,000 . Thus, it was concluded that there was no correlation between variables or there was no multicollinearity problem. 
Pipit Ramadhanti et.al. The effect of student activity in organizations on learning achievement and soft skill improvement.

Table 3 Multicollinearity Test X1 (Organization) with Y1 (Learning Achievement)

\begin{tabular}{|c|c|c|c|c|c|c|c|c|}
\hline \multicolumn{9}{|c|}{ Coefficients $^{a}$} \\
\hline \multirow{2}{*}{\multicolumn{2}{|c|}{ Model }} & \multicolumn{2}{|c|}{$\begin{array}{c}\text { Unstandardized } \\
\text { Coefficients }\end{array}$} & \multirow{2}{*}{$\begin{array}{c}\text { Standardized } \\
\text { Coefficients }\end{array}$} & \multirow[b]{2}{*}{$\mathrm{T}$} & \multirow[b]{2}{*}{ Sig. } & \multicolumn{2}{|c|}{ Collinearity Statistics } \\
\hline & & B & Std. Error & & & & Tolerance & VIF \\
\hline \multirow[t]{2}{*}{1} & (Constant) & 3,210 &, 182 & & 17,648 &, 000 & & \\
\hline & Organisasi & ,012 &, 006 &, 225 & 2,024 & ,046 & 1,000 & 1,000 \\
\hline
\end{tabular}

Table 4: Multicollinearity Test X1 (Organization) with Y2 (Soft Skills)

\begin{tabular}{|c|c|c|c|c|c|c|c|c|}
\hline \multicolumn{9}{|c|}{ Coefficients $^{\mathrm{a}}$} \\
\hline & & \multicolumn{2}{|c|}{$\begin{array}{c}\text { Unstandardized } \\
\text { Coefficients }\end{array}$} & $\begin{array}{l}\text { Standardized } \\
\text { Coefficients }\end{array}$ & \multirow[b]{2}{*}{$\mathrm{T}$} & \multirow[b]{2}{*}{ Sig. } & \multicolumn{2}{|c|}{ Collinearity Statistics } \\
\hline \multicolumn{2}{|c|}{ Model } & B & Std. Error & Beta & & & Tolerance & VIF \\
\hline \multirow[t]{2}{*}{1} & (Constant) & 58,262 & 4,324 & & 13,475 &, 000 & & \\
\hline & Organisasi & 1,514 & 141 &, 775 & 10,761 &, 000 & 1,000 & 1,000 \\
\hline
\end{tabular}

a. Dependent Variable: Soft Skills (Y2)

Source: calculated data from SPSS version 23

\section{c. Uji Heteroskedastisitas}

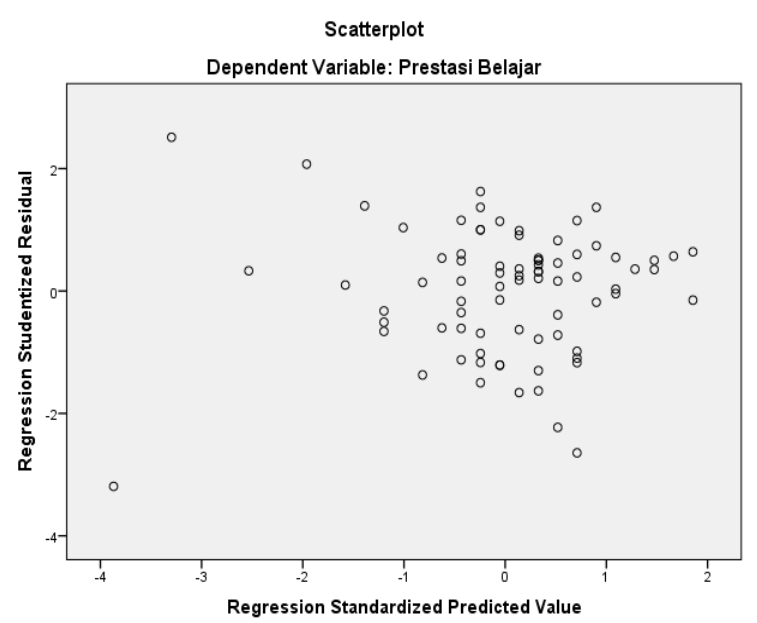

Figure 4: Heteroscedasticity Test X1 with Y1 (Learning Achievement)

Based on Figures 4 and 5 of the scatterplot graph, it could be seen that the points spread randomly and spread above and below the number 0 on the $y$-axis in the scotterplot graph. Thus, it was concluded that this regression model did not occur heteroscedasticity.

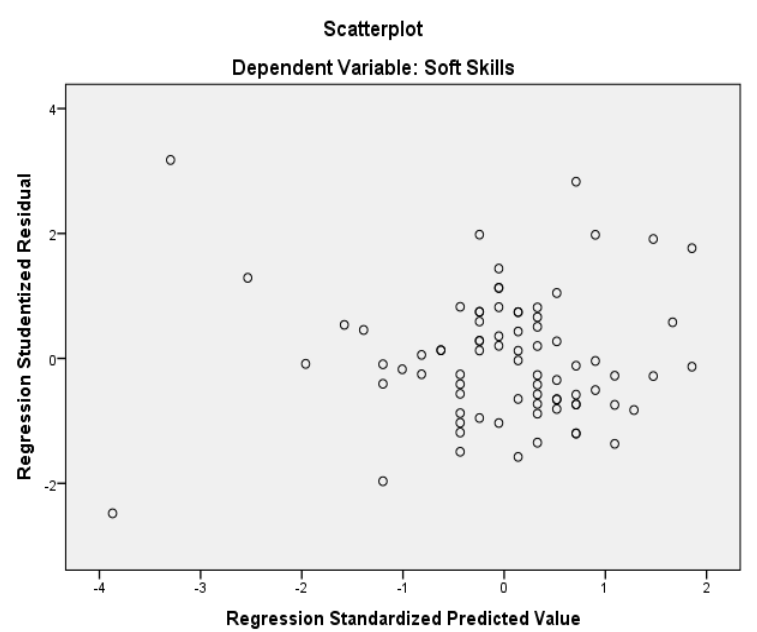

Figure 5: Heteroscedasticity Test X1 with Y2 (Soft Skills)

\section{RESULT}

The results of simple regression analysis of the organization's independent variable $(\mathrm{X})$ on the dependent variable of learning achievement (Y1) and soft skills were described in the table below:

Table 5. Organizational Simple Analysis Test Results (X1) with Learning Achievement (Y1)

\begin{tabular}{|c|c|c|c|c|c|c|c|c|}
\hline \multicolumn{9}{|c|}{ Coefricients } \\
\hline & & \multicolumn{2}{|c|}{$\begin{array}{l}\text { Unstandardized } \\
\text { Coefficients }\end{array}$} & $\begin{array}{c}\text { Standardize } \\
\text { d } \\
\text { Coefficients }\end{array}$ & \multirow[b]{2}{*}{$\mathrm{T}$} & \multirow[b]{2}{*}{ sig. } & \multicolumn{2}{|c|}{ Collinearity Statistics } \\
\hline \multicolumn{2}{|c|}{ Model } & B & Std. Error & Beta & & & Tolerance & VIF \\
\hline 1 & (Constant) & 3,210 &, 182 & & $\begin{array}{r}17,64 \\
8\end{array}$ &, $\mathrm{OOO}$ & & \\
\hline & Organisasi &, 012 &, 006 &, 225 & 2,024 &, 046 & 1,000 & 1,000 \\
\hline
\end{tabular}


The simple regression analysis equation is as follows $\mathrm{Y}=3.210+0.12 \mathrm{X}$ or learning achievement $=3.210+0.012$ (organization). From the conclusion above, it can be concluded that:

a. The constant of 3.210 stated that if there was no organization, the learning achievement value was 3.210 . b. The X1 regression coefficient had an influence on learning achievement; it is 0.012 , means that the higher activeness of the organization, the learning achievement will increase by 0.012 .

Table 6. Organizational Simple Analysis Test Results (X1) with Soft Skills (Y2) Coefficientsa

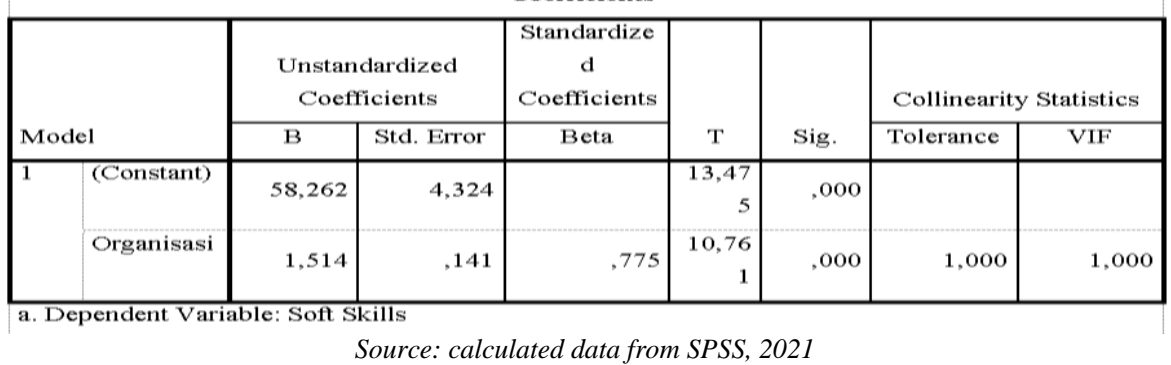

The simple regression analysis equation was as follows $\mathrm{Y}=58.262+1.514$ or soft skills $=3.210+1.514$ (organization). From the conclusion above, it could be concluded that:

a. The constant of 58.262 states that if there was no organization, the soft skills value was 58.262

b. The X1 regression coefficient had an influence on soft skills, which was 0.012 , which means that the higher the organizational activity, the learning achievement will increase by 1.514 .

\section{DISCUSSION}

1. The Influence of Organizational Activity on Students of Economics and Business Faculty of Nusantara University PGRI Kediri Achievement.

Based on the results of the analysis, this study explains that student activity in the organization has an influence on learning achievement by using simple regression data analysis. The coefficient of determination is $0.051=5.1 \%$, this proves that activity in the organization is able to explain learning achievement by $5.1 \%$. Student activity if it is associated with learning achievement is one of the tools to motivate themselves or a reason for students to carry out learning activities more actively and seriously. If students realize that learning and self-development are considered important to achieve their goals, they are likely to be active in learning and following them. The results of being active in the organization are expected to be applied when studying in class so that the learning process can run as desired and in line with the objectives. This agrees with the results of research (10) and (11) which state that the organization has a positive effect on learning achievement.

\section{Organizational influence on improving the soft skills on Economics and Business Faculty of Nusantara University PGRI Kediri Students.}

Based on the results of the analysis, this study shows that student activity in the organization has an influence on soft skills by using simple regression data analysis. The coefficient of determination is $0.601=$ $60.1 \%$, this shows that activeness in the organization is able to explain soft skills of $60.1 \%$. In improving soft skills, if a student plays an active role in the organization he is participating in, the student will feel the development in him which consists of increasing work ethic, communication, collaboration and other soft skills components quickly and being more 
organized. An organizational activity is quite influential on the improvement of soft skills, because if a student does not play an active role in the organization, it can affect his soft skills or development which will be very useful for the pattern of life and needed in the industrial world. This is in line with the results of research (12) and (13) that the organization has a positive effect on soft skills.

\section{CONCLUSION}

The results of this study can be explained as follows: 1) Student activity in organizations has a positive and significant influence on learning achievement in Economics and Business Faculty students of Nusantara University PGRI Kediri class 2018. This is indicated from the t-test of 2.024 with t table of 1.992 and a significant value of $0.046<0.05$. The value of the coefficient of determination of $0.051=5.1 \%$ indicates that student activity in the organization is only able to explain learning achievement by $5.1 \%$ and the remaining $94.9 \%$ is explained by other variables. 2) Student activity in organizations has a positive and significant impact on improving soft skills in Economics and Business Faculty students of Nusantara University PGRI Kediri class 2018. This is indicated from the t-test of 10,761 with a ttable of 1.992 and a significant value of $0.000<0.05$. The coefficient of determination of $0.601=60.1 \%$ indicates that student activity in the organization is able to explain soft skills by $60.1 \%$ and the remaining $39.9 \%$ is explained by other variables. Student activity simultaneously affects the learning achievement of Economics and Business Faculty of UNP Kediri students. It is known that the result of the calculated F test is 4.097 and the F table is 3.970. Meanwhile, simultaneously the activeness of students in organizations towards improving soft skills in Economics and Business Faculty students at Nusantara University PGRI Kediri class 2018 has an influence with the results of the calculated $\mathrm{F}$ value of 115,790 > F table 3,970.

\section{Acknowledgement: None}

Conflict of Interest: None

\section{Source of Funding: None}

\section{REFERENCES}

1. Sholikhah A. Pengaruh Keaktifan Mahasiswa Dalam Organisasi Terhadap Prestasi Belajar Mahasiswa Jurusan Pendidikan Ekonomi FE Unesa Angkatan 2015. J Pendidik Ekon. 2018;6(2):76-80.

2. Santoso IB. Pengaruh Keaktifan Organisai Dan Motivasi Belajar Terhadap Prestasi Belajar Pengurus Unit Kegiatan Mahasiswa Universitas Negeri Yogyakarta Periode 2019-2020. J Ilmu Manaj. 2019;16(2):102-13.

3. Elfindri. Soft Skills Untuk Pendidik. Jakarta: Baduose Media; 2011.

4. Irmayanti, Nuraina E, Styaningrum F. Pengaruh keaktifan mahasiswa dalam berorganisasi terhadap kesiapan kerja dengan soft skill sebagai variabel intervening. Rev Account Bus [Internet]. 2020;1(1):53-66. Available from: http://202.93.229.169/index.php/REAS/art icle/view/335

5. Mohyi A. Teori dan Perilaku Organisasi. Malang: UMMPress; 2018.

6. Rosyid MZ. Prestasi Belajar. Malang: Literasi Nusantara; 2019.

7. Helmi M. Metode Pembelajaran Bridwatching Dalam Meningkatkan Prestasi Belajar IPA Siswa SDLB C. Universitas Islam Negeri Maulana Malik Ibrahim Malang; 2012.

8. Widarto. Pengembangan Soft Skills Mahasiswa Pendidikan Vokasi Melalui Clop Work. Yogyakarta: Paramitra; 2011.

9. Siregar S. Metode Penelitian Kuantitatif Dilengkapi Dengan Perbandingan Perhitungan Manual \& SPSS. Jakarta: Kencana; 2017. 8 p.

10. Zainuddin M, Sawiji H, Murwaningsih T. Pengaruh Keaktifan Berorganisasi dan Komunikasi Interpersonal Terhadap Prestasi Belajar Ilmu Organisasi Mahasiswa PAP FKIP UNS. JIKAP. 2020;4(1):39-42.

11. Chandra P, Kartika WT. Pengaruh Keaktifan Mengikuti Organisasi Siswa 
Pipit Ramadhanti et.al. The effect of student activity in organizations on learning achievement and soft skill improvement.

Intra Sekolah (OSIS) Terhadap Hasil Belajar Pendidikan Agama Islam (PAI) Di Bengkulu. 2021;

12. Siswanto I, Arifah IWN, Ramadhan FEN. Pengaruh Keaktifan di Organisasi dan IPK terhadap Softskills dan Kesiapan Menjadi Guru Mahasiswa Pendidikan Teknik Otomotif. Taman Vokasi. 2019;7(2):106.

13. Idauli AR, Fitri E, Supriyono. Peran Organisasi Kemahasiswaan Terhadap Perkembangan Keterampilan Non Teknis
Mahasiswa Universitas Pendidikan Indonesia. AoEJ. 2013;48:5-6.

How to cite this article: Ramadhanti P, Afandi TY, Prastyaningtyas EW. The effect of student activity in organizations on learning achievement and soft skill improvement. International Journal of Research and Review. 2021; 8(8): 488-495. DOI: https:// doi.org/10.52403/ijrr.20210866 